VoL. CLX, 21: 22]

Brigimal strtiotén.

\section{EXTENSIVE CALCIFICATION OF PLEURITIC EXUDATION CAUSING CURVATURE OF THE SPINE.}

BY THOMAs DWIGHT, M.D., LL.D.

Parkman Professor of Anatomy at the Harvard Medical School.

IsOLATED calcifications of this kind are often scen, but specimens like the present one are very rare; therefore this observation on the body of a man, aged forty-five, who had died of uremia, seems worth recording. There is no elinical history, but there had been very extensive pleuritic adhesions throughout the back and more or less of the side of the right chest, forming a very thick layer between the walls and the lung. A flattened piece of what seemed to be bone, some

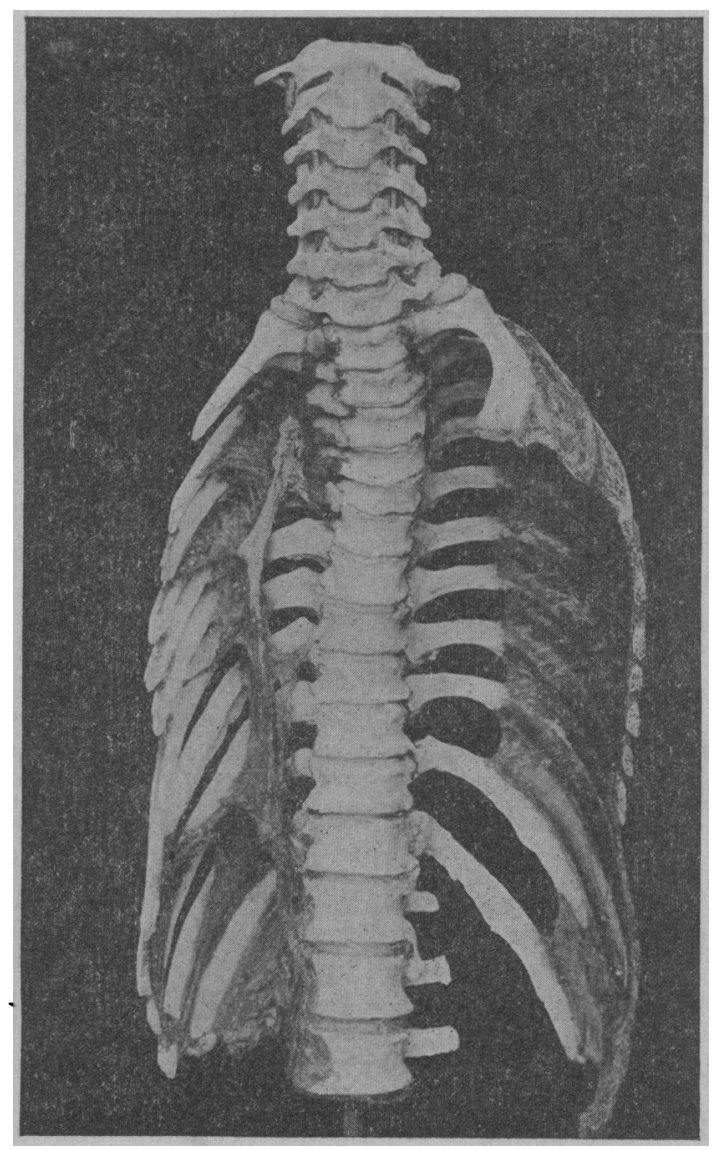

8 or $10 \mathrm{~cm}$. long, probably not over $1 \mathrm{~cm}$. broad, was found free in the back of the right chest, pressing into the lung. It apparently was not far distant from the chief piece to be described presently. Moreover, a thin circular bony disk about $2 \mathrm{~cm}$. in diameter was found far forward in the right side of the parietal pericardium, where it was in contact with the right pleura.

The chief bar, which is shown in the figure, consists of the union of a large number of what would seem to have been originally distinct spicules, which must have appeared in the degenerate fibrous tissue and later have been fused.
The greatest length of practically continuous bone is nearly $11 \mathrm{~cm}$. It is flattened, with the greatest breadth of more than $2 \mathrm{~cm}$. at the upper part. This bony bar does not lie against the wall of the thorax, but projects inward so that where it crosses the eighth rib it is nearly $1 \mathrm{~cm}$. in front of it. The bar is also convex laterally. When the specimen was fresh, fibers could be seen radiating from the bone in many directions, comparatively few of which appear in the photograph, which, however, gives a very fair idea of the nature of the tissue. The particular band of fibrous tissue in which the change has occurred may be seen extending from the first rib to the diaphragm, of which a small piece is preserved, with lateral expansions to several of the ribs.

I am indebted to the kindness of Dr. E. H. Nichols for an analysis of a piece from the upper part of the bar. He finds that calcification has taken place in dense fibrous tissue and that there is no true bone. It would be impossible with the naked eye to determine the point. Unfortunately the two pieces found free were both lost. The long one was of the same general character as the bar shown in the figure. The round thin disk found in the pericardial laycr looked quite like true bone.

Perhaps the most practical deduction from this observation is the effect that this bony bar must have had in causing the twisted curvature of the spine, which the photograph shows, but to which it does not do full justice. Looked at from behind, the right ribs from the third to the ninth are brought near together at their angles and project strongly backward, while the left ones from their tubercles to their angles extend nearly straight outward, so that the two sides of the chest are extremely uneven. The bodies of the fourth and fifth thoracic vertebræ are much lower on the right than on the left and are fused totogether. I shall not presume to discuss the clinical aspects of the case beyond observing that this bar would oppose, after the fashion of a bowstring, any effort to correct the deformity. After the bar had been discovered I had the body xrayed, but though the structure was shown, there was nothing sufficiently striking to warrant the reproduction of the plate. The bar was much less opaque than the ribs. Presumably its faintness is due to the fact that it is not true bone.

The specimen will be found in the Warren Museum of the Harvard Medical School.

\section{THE ETIOLOGY AND DIAGNOSIS OF IRITIS.*}

$$
\text { BY PETER hUNTER THOMPSON, M.D., BOBTON. }
$$

THe iris, situated as it is in intimate relation with other parts of the eye which frequently become inflamed; being made up chiefly of blood vessels and a stroma composed of a framework of connective tissue containing bundles of radiating and interlacing fibers with pigment cells more or less numerous, nerves and unstriated muscle tissue; covered anteriorly by a layer of

* Read at a meeting of the New England Ophthalmological Society, $*$ Read at a m
March 9, 1909 . 